\title{
SEMEN ANALYSIS FROM A POINT OF VIEW OF GYNECOLOGIST AND RECENT DEVELOPMENTS
}

\author{
Omer Lutfi TAPISIZ ${ }^{1}$, Sadiman Kiykac ALTINBAS ${ }^{1}$, Faruk ABIKE ${ }^{2}$, Umit GOKTOLGA ${ }^{1}$ \\ ${ }^{1}$ Department of Obstetrics and Gynecology, Etlik Zubeyde Hanim Training and Research Hospital, Ankara, Turkey \\ 2 Department of Obstetrics and Gynecology, Ankara Medicana International Hospital, Ankara, Turkey
}

\begin{abstract}
SUMMARY
Infertility is defined as the time of one year of unprotected intercourse without conception and affects approximately $15 \%$ of the couples. Data available over the years reveal that pathology is found among 55\% of cases in women, 35\% of cases in men and the remaining $10 \%$ of cases are defined as unexplained infertility. Male infertility is commonly due to deficiencies in the semen and semen quality is used as a surrogate measure of male fecundity. A semen analysis evaluates certain characteristics of a male's semen and the sperm contained in the semen. It should be the first laboratory investigation for men while evaluating a couple's infertility. Here, we tried to review the semen analysis as a very important laboratory investigation in evaluating the infertile couples with all points in the light of last published World Health Organization (WHO) criteria.
\end{abstract}

Key words: male infertility, semen analysis, spermiogram, World Health Organization (WHO)

Journal of Turkish Society of Obstetrics and Gynecology, (J Turk Soc Obstet Gynecol), 2012; Vol: 9 Issue: 1 Pages: 25-31

\section{JINEKOLOG GÖZÜ ILE SEMEN ANALIZİ VE SON GELIŞMELER}

ÖZET

İnfertilite, bir yıldır korunmasız cinsel ilişkiye rağmen konsepsiyonun oluşmaması olarak tanımlanır ve yaklaşık olarak çiftlerin \%15'ini etkiler. Ylllar içindeki mevcut data, patolojinin \%55 olguda kadınlarda, \%35 olguda erkeklerde olduğunu ve geri kalan \%10 olgunun da açıklanamayan infertilite olarak tanımlandı̆̆ını göstermektedir. Erkek infertilitesi sıklıkla semendeki bir yetersizliğe bağlıdır ve semen kalitesi erkek fekunditesinin ölçümünde kullanılır. Semen analizi erkek semeninin belirli özelliklerini ve semenin içerdiği spermi değerlendirir. İnfertil bir çiftin değerlendirilmesinde erkek için yapılacak ilk laboratuvar incelemesi semen analizi olmalıdır. Biz de burada, infertil çiftlerin değerlendirilmesinde çok önemli bir laboratuvar incelemesi olan semen analizini Dünya Sağllk Örgütü'nün (DSÖ) yayınladı̆̆ı son kriterler ışı̆̆ında bütün yönleri ile gözden geçirmeye çalıştık.

Anahtar kelimeler: Dünya Sağlık Örgütü (DSÖ), erkek infertilitesi, semen analizi, spermiogram

Türk Jinekoloji ve Obstetrik Derne ği Dergisi, (J Turk Soc Obstet Gynecol), 2012; Cilt: 9 Sayl: 1 Sayfa: 25- 31

Address for Correspondence: Ömer Lütfi Tapısız. Turan Güneş Bulvarı Sedir Sitesi C2 Blok No: 6, Oran 06450, Ankara Phone: (0505) 3197577

e-mail: omertapisiz@yahoo.com.tr

Received: 15 April 2011, revised: 27 July 2011, accepted: 11 August 2011, online publication: 08. December 2011 


\section{INTRODUCTION}

According to the definition by the World Health Organization (WHO) infertility is the absence of conception despite one year of regular sexual intercourse of a sexually active couple without contraceptive protection $^{(1)}$. Nearly $15 \%$ of couples fail to achieve conception in a 1 year period and present to receive treatment for infertility ${ }^{(2)}$. When reviewed, $55 \%$ of the reasons for infertility are found to be male-related and $35 \%$ to be female-related, while $10 \%$ constitutes infertility of unknown origin(3). In approaching to an infertile couple, the first laboratory evaluation to be performed will normally be a semen analysis in the process of investigating the presence or absence a male-related infertility reason. We, in this review, aimed to discuss semen analysis, which is of major importance in evaluating an infertile couple, in all its aspects and taking the latest criteria into consideration.

\section{SEMEN ANALYSIS AND INFERTILITY}

Abnormal sperm analysis results are observed in the major part of the infertility associated with male factor. First assessment should have at least a properly performed semen analysis. If an abnormal result is encountered, other sampling should be performed after at least 4 weeks ${ }^{(4)}$. It should be noted that semen parameters may differ very seriously in time and that may show temporal and seasonal differences even in fertile males. Therefore, performing more than one examination in the evaluation of semen analysis is important with respect to increase the degree of accuracy. Presence of a normal semen analysis will often ensure an important male factor to be excluded if there is no complaint or suspicion concerning sexual dysfunction. In contrast, determination of abnormal semen analysis will require additional endocrinological, urological and genetic investigations.

\section{COLLECTING SEMEN SAMPLE}

It is important to have a certain standard method that is explained in detail for collecting semen. Thus a definite standardization will be ensured for evaluating the results of analysis, administering treatment protocols and making comparisons between individuals. Semen sample should be collected following at least a 2-day (2 to 7 days) sexual abstinence. To ensure standardization, a 3-4 days period of sexual abstinence will be appropriate. While short period of sexual abstinence causes decreases in the volume and density of semen, that of long causes increases in its volume, density and proportion of dead, immotile and morphologically abnormal sperms. Ideally, semen should be collected by masturbation in a sterile and dry, wide-rimmed, glass of plastic container with no previous spermicide toxicity. However, collection can also be performed during intercourse using specially produced plastic condoms (latex condoms affect the vitality and motility of sperms) containing no spermicidal agents. Collection by withdrawal during intercourse is not recommended since this causes the loss of the first portion of sperm. The importance of collecting all the semen ejaculated should be kept in mind, because, composed mostly of prostate fluid, the first portion contains the highest sperm concentration, while the last portion is particularly vesicular fluid forming the major portion of semen. Therefore, it is essential to avoid escapes and splits while collecting semen. Germ, spit and lubricant contaminations should be avoided during semen collection. Previous to collection hands and genitals should be washed with soap and rinsed thoroughly with water. Soap and other lubricants should not be used during masturbation. Collecting semen in an isolated, special environment within or near laboratory will be the most appropriate approach. It should be remembered that emotional stress and tension have negative effects on semen parameters particularly on volume, count and motility. (5). Therefore, the importance of performing collection in an environment in which patient will feel comfortable and peaceful should always be kept in mind. If collection is considered to be more proper to be done at home, semen sample should be ensured to be transferred quickly while being kept at room or body temperature. Semen sample taken in a way other than collecting method should be evaluated within an hour(4).

\section{MACROSCOPIC ANALYSIS of SEMEN}

Fresh ejaculate is white or grayish white opaque substance of a viscous nature. It has a typical odor. It 
liquefies generally within 10-20 minutes and becomes blurred.

\section{a) Color and odor}

Appearance of normal semen is homogenous, grayishwhite in color and opaque. The lower the concentration of semen the less opaque it seems. Depending on the prolongation of sexual abstinence, it may become yellowish in color. In case of presence of erythrocyte in semen, the color will become reddish brown. Its typical color is thought to be resulting from sperm oxidation due to prostate secretions ${ }^{(5)}$. The odor and color of semen may differ according to duration of sexual abstinence and presence of infection.

\section{b) Liquefaction time}

Semen is coagulated during ejaculation by seminal vesicle secretion containing semenogelin I, and liquefies at room temperature within approximately 20 minutes. Liquefaction occurs by means of proteolytic enzymes (fibronilisine, fibrinokinase, aminopeptidase) secreted by prostate. In evaluation of liquefaction, ejaculate is placed in an incubator at $37^{\circ} \mathrm{C}$ and allowed to be liquefied. Liquefaction time more than 60 minutes or no liquefaction longer is pathologic showing lack of prostatic enzyme or inadequate prostate function ${ }^{(6)}$. In cases of no liquefaction or excess viscosity mechanical stirring (e.g., withdraw and release by a pipette or an injector) or dissolve in an enzyme (e.g., $1 \mathrm{gr} / 1$ of bromelain or $0.5 \mathrm{cu} / \mathrm{ml}$ of plasmin) may be needed. It should be kept in mind that these practices may affect seminal plasma biochemistry and sperm motility and morphology(6).

\section{c) Viscosity}

Normal semen has a viscous texture. Increase in viscosity may occur due to hypofunction of vesicula seminalis. High viscosity may affect sperm motility and concentration. İncrease in viscosity may reduce the success of intrauterine insemination (IUI) and in vitro fertilization (IVF). For evaluation, the sample is withdrawn into pipette and observed leaving the pipette drop by drop under the effect of gravity. In case of abnormal viscosity, the sample stretches like a thread. If the elongation is more than $2 \mathrm{~cm}$ it is considered to be pathological. Evaluation of elongation may be performed by using a glass $\operatorname{bar}^{(7)}$.

\section{d) Volume and pH of ejaculate}

Normal ejaculate volume is expected to be between 1.5 and $5.0 \mathrm{ml}^{(4)}$. In determining the volume, it is recommended to place the sample in a wide-rimmed container and use gravimetric method. Measuring the volume by aspiration is not recommended $(0.3-0.9 \mathrm{ml}$ of mismeasurement). Normal $\mathrm{pH}$ of semen is $>7.2$. Following liquefaction, preferably within 30 minutes, and 1 hour at the most, a $\mathrm{pH}$ assessment should be done. Vesicula seminalis secretions contained in semen are alkaline while prostatic secretions have acidic properties. Both secretions should be in a certain balance. It should be noted that $\mathrm{pH}$ of semen may increase up to 8.0 in acute infections (infections of prostate, vesicula seminalis, epididymis). No or little ejaculate volume should suggest an ejaculation failure, short sexual abstinence, collection defects, congenital absence of vas deferens, ejaculatory duct obstruction, hypogonadism or retrograde ejaculation. Evaluation of other semen parameters will help in differentiating the reason. The majority of semen is generated by the vesicula seminalis that develops from the same embryological origin as the vas deferens. The secretion of the vesicula seminalis is alkaline and contains fructose. In majority of the men without bilateral vas deferens, the vesicular seminalis is absent or hypoplastic. In this case, semen will be acidic $(\mathrm{pH}<7.2)$, small in volume and of a quality containing no or little fructose ${ }^{(8)}$. Again in ejaculatory duct obstruction, the quality of semen will be similar and fructose concentration will be reduced according to the level of obstruction. If ejaculatory ducts are bilaterally completely obstructed, semen will be acidic, and will contain no fructose or sperm (for it contains only prostatic secretion). Also in hypogonadal men, since the testicular androgen production is low, vesicula seminalis and prostate, both of which are stimulated by androgens, will not be able to produce adequately and ejaculate volume will be reduced. In the event that ejaculate volume is less than $1 \mathrm{ml}$ and that factors such as hypogonadism, congenital absence of bilateral vas deferens, collection problems or short sexual abstinence period are excluded, a post-ejaculator urinary analysis should be performed to determine retrograde ejaculation Finding sperm in post-ejaculator urinary analysis performed in men with no or little semen volume and azoospermia should suggest retrograde ejaculation(4). 


\section{MICROSCOPIC ANALYSIS of SEMEN}

In this examination sperm count and motility characteristics, morphological structure, presence or absence of agglutination, leukocyte and round cell staining and count, and, if necessary, vitality investigations are performed ${ }^{(5)}$. Furthermore, according to criteria defined by the WHO in 2010 , sperm aggregation is determined by evaluation of binding of immotile sperms to motile or immotile sperms, mucus fibers, non-sperm cells and cellular wastes ${ }^{(9)}$. Once the semen is liquefied, examination of unstained wet preparations using phase-contrast optical system will be more advantageous. Through this initial examination, important information about the concentration and motility of sperm is obtained(5).

\section{a) Agglutination}

This is a status in which motile sperms clump and stick together. Types of agglutinations may be in head-tohead- tail-to-tail or head-to-tail fashion. Presence of plurality of tail-to tail motile dimers may be suggestive of the presence of antisperm antibodies ${ }^{(5)}$. Who has defined four groups for the purpose of grading agglutination: Grade I, isolated, $<10$ spermatozoa per agglutination, most of the sperms are free; Grade IIModerate, 10-50 spermatozoa per agglutination, free sperms are present; Grade III, Extended >50 spermatozoa per agglutination, some spermatozoa are free; Grade IV-Whole, all spermatozoon are agglutinated (9).

\section{b) Sperm count and concentration}

Neubauer hemocytometer, Makler chamber or single use counting devices (Mikro-Cell) are used to determine sperm cell counts in ejaculate(5). For sperm count, hemocytometer counting chambers of $100 \mu \mathrm{m}$ depth are recommended. Semen should be diluted to correctly count the sperms. The degree of dilution is determined according to sperm cell count obtained per image square for $200 \mathrm{X}$ or $400 \mathrm{X}$ magnification in fresh preparation and the number of sperms per milliliter is calculated ${ }^{(10)}$. For determining sperm concentration, at least 200 cells are counted following a suitable dilution. Calculation is made according to following formulas using developed Neubauer hemocytometer;
Concentration $(C)$ : Total counted sperms $(\mathrm{N}) /$ number of rows evaluated $\mathrm{x} 1$ / volume of one row $\mathrm{x}$ dilution rate

$C=(\mathrm{N} / \mathrm{n}) \times(1 / 20) \times$ dilution factor (n: number of square where count is performed)

Normal values according to the WHO criteria defined in 2010 are stated as spermatozoa/ml: $15 \times 106$, total sperm count: 39x106(9).

If no sperm is seen in microscopic examination, a new fresh preparation is prepared. If again no sperm is seen, then azoospermia may be suspected. Semen sample is centrifuged at high speed ( (3000g/15 minutes), and concluded as criptozoospermia and azoospermia if and if not, respectively, sperm cells are detected. The incidence of azoospermia among all men is $1 \%$, while it is $10-15 \%$ in infertile men ${ }^{(11)}$. In new recommendations, use of fixed, non-centrifuged samples for evaluation and indicating the sensitivity of counting method are underlined. On the other hand, it has been emphasized that centrifuge methods are needed in sufficient cell collection for therapeutic methods and in postvasectomy semen evaluation ${ }^{(9)}$.

\section{Sperm motility}

Spermatozoon need to be actively motile to pass cervical mucus and fertilize the ovum in tuba uterine. Evaluation of sperm motility should be performed within 60 minutes, preferably 30 minutes, following semen liquefaction. Evaluation should be performed by counting 200 sperm cells in total at room temperature or $37^{\circ} \mathrm{C}$, at the depth of $20 \mu \mathrm{m}$ and in $200 \mathrm{X}$ or $400 \mathrm{X}$ magnifications. Evaluating motility subjectively causes different laboratory results at present. To prevent this and ensure objectivity, the WHO has determined sperm motility evaluation criteria and 3 groups have been defined(9):

- Progressively motile; actively motile whatever its speed (both linear and wide circular,

- Non-progressively motile; all motility patterns without progression (swimming in tight circle),

- Immotile

According to $\mathrm{WHO}$, progressively motile sperm rate of minimum $32 \%$ and total motile sperm rate of minimum $40 \%$ has been defined as normal ${ }^{(9)}$. According to previous criteria published by the WHO in 1999 gathering progressive motility in single group 
and change in determined proportions (in 1999, fast progressive motility $\geq 25 \%$, fast progressive + slow progressive motility $\geq 50 \%$ ) forms the main differences (12) constitute main differences. Total motile sperm count (ejaculate volume $\mathrm{x}$ Concentration $\mathrm{x}$ proportion of progressively motile sperm) is an important parameter. In circumstances of total motile sperm count of $<5 \times 106$, treatment using techniques supporting reproduction will be a more appropriate approach(13)

\section{c) Sperm vitality}

Vitality of sperms is defined by membrane integrity of cells. Proportion of vital sperms is determined by counting total of 200 cells. According to the WHO criteria this is recommended to be performed routinely on all semen samples. If particularly the proportion progressively motile sperms is $\leq 40 \%$, vitality test should definitely be performed ${ }^{(9)}$. In evaluation of sperm vitality, staining tests (Eosin Y, Eosin-nigrosin) and hypoosmotic swelling (HOS) test are performed. According to the latest WHO criteria vitality of more than 58 in staining tests and HOS test has been determined as normal reference value ${ }^{(9)}$.

\section{d) Differentiation of round cells and leukocytes}

In semen, other than sperms, there are round cells such as epithelium and prostate cells, spermatogenic cells (immature germ cells) and leukocytes. In classical semen analysis, immature germ cells and leukocytes can easily be confused with each other. Leukocytes in ejaculate are specifically formed of neutrophills. In circumstances such as infection, reduction of ejaculate volume and sperm dysfunction due to oxidative stress there may be excess of leukocyte in semen. In normal semen leukocyte count must be $<1 \times 10^{6} / \mathrm{ml}$. When the number of round cell in semen is $>1 \times 10^{6} / \mathrm{ml}$, leukocyte diagnosis test may be performed. In determining leukocyte count, test for the presence of intracellular peroxidase and specific antigen tests are used. In the test based on intracellular peroxidase, leukocytes are stained in brown using benzidine and hydrogen peroxide added to the medium. Leukocytes are thus differentiated from other cells ${ }^{(14)}$.

\section{e) Morphological evaluation}

Two smears are prepared from semen sample and allowed to dry in the air. After that, these smear samples are fixed and stained (Papanicolaou, Shorr, Diff-Quick).
Then sperm morphology is evaluated microscopically at 1000X magnification. In normal sperm morphology, the head should be oval in shape and acrosome should constitute the $40-70 \%$ of the front part of the head. Vacuole number in head section should $<2$ and vacuole should not be larger than $20 \%$ of the area occupied by the head. As for the tail section: the tail should not be

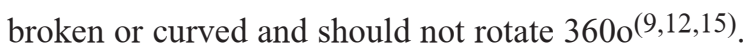
Normal reference values for sperm morphology are $\geq$ $4 \%$ in 2010 WHO criteria ${ }^{(9)}$, while are $>3 \%$ in that of 1992(16). As for the 1999 WHO declaration, IVF success has been stated to be markedly reduced when normal sperm morphology is $<15 \%(12)$. The reference value for normal sperm morphology determined by Kruger is $>14 \%{ }^{(15)} .1999$ vs. 2010 the WHO reference values for normal sperm morphology are given in Table I.

Table I: Normal sperm morphology criteria determined WHO in 1999 an $2010^{(9,12)}$.

\begin{tabular}{|c|c|c|}
\hline PARAMETERS & WHO 1999 (12) & WHO 2010 (9) \\
\hline \multicolumn{3}{|l|}{ Head } \\
\hline Width & $2.5-3.5 \mu \mathrm{m}$ & $2.8 \mu \mathrm{m}$ \\
\hline Length & $4.0-5.0 \mu \mathrm{m}$ & $4.1 \mu \mathrm{m}$ \\
\hline Length/witdh ratio & $1.5-1.75$ & 1.5 \\
\hline Acrosomal region & \multicolumn{2}{|c|}{ should cover $40-70 \%$ of the head } \\
\hline \multicolumn{3}{|l|}{ Neck and middle piece } \\
\hline Width & $<1.0 \mu \mathrm{m}$ & $0.6 \mu \mathrm{m}$ \\
\hline Length & $\begin{array}{l}1.5 \mathrm{x} \text { of the lengtl } \\
\text { of the head }\end{array}$ & $4.0 \mu \mathrm{m}$ \\
\hline Cytoplasmic residues & \multicolumn{2}{|c|}{ normal head area $<1 / 3$} \\
\hline \multicolumn{3}{|l|}{ Tail } \\
\hline Length & \multicolumn{2}{|c|}{$\sim 45 \mu \mathrm{m}$} \\
\hline Width & \multicolumn{2}{|c|}{$<$ middle piece } \\
\hline
\end{tabular}

\section{NORMAL REFERENCE VALUES IN SEMEN ANALYSIS}

Limits which we consider as normal reference values in semen analysis are values obtained based on the comparison of semen parameters in fertile and infertile couples ${ }^{(17-19)}$. On the other hand, it should be recognized that normal reference values do not always reflect the absolute minimum values necessary for pregnancy to possibly occur. There are many men who are fertile despite being out of normal limits and there are those who are infertile despite being within normal limits. However, in approaching a normal couple, abnormal semen analysis results suggest male factor 
and require additional clinical and laboratory evaluations (4). The importance of evaluating all parameters as a whole should always be remembered. For example, if semen volume, sperm motility and abnormal sperm ratios are at or within normal limits, slightly low sperm density would not be a very important issue. Among semen parameters, those that have the greatest effect on fertility are concentration, motility and morphology. The risk in terms of fertility increases 2-3 fold if there is a problem related to one of these parameters, 5-7 fold if there is a problem in two and 16-fold if in all three ${ }^{(20)}$.

How to perform semen analysis has been determined in detail by the WHO through new regulations made over the years $(9,12,16,21)$. Presently, however, methodology and reliability of semen analyses performed in many centers show marked differences. What is recommended is to perform semen analysis in laboratories with certain standards confirmed by quality control programs (eg., Clinical Laboratory Improvement Amendments CLIA ; www.hcfa.gov/medicaid/clia/cliahome.htm) ${ }^{(22)}$. The WHO has published new reference values for semen parameters in $2010^{(9)}$. In Table II, the most recent normal reference values for semen analysis published by the WHO are given in comparison with those published in $(9,12)$.

Table II: Lower reference values accepted for semen parameters published by the WHO in 1999 and 2010.

\begin{tabular}{lll}
\hline PARAMETERS & WHO 1999 (12) & WHO 2010 (9) \\
\hline Semen volume $(\mathrm{ml})$ & $\geq 2$ & $1.5(1.4-1.7)$ \\
Total sperm count $\left(10^{6} / \mathrm{ejaculate}\right)$ & 40 & $39(33-46)$ \\
Sperm concentration $\left(10^{6} / \mathrm{ml}\right)$ & 20 & $15(12-16)$ \\
Total motility $(\mathrm{PR}+\mathrm{NP}, \%)$ & $(\mathrm{a}+\mathrm{b}+\mathrm{c})>50$ & $40(38-42)$ \\
Progressive motility $(\mathrm{PR}, \%)$ & $\mathrm{a}+\mathrm{b}>50, \mathrm{a}>25$ & $32(31-34)$ \\
Vitality (vital spermatozoa, \%) & 75 & $58(55-63)$ \\
Sperm morphology & & \\
(Normal forms, \%) & $30(\mathrm{WHO})$, & $\geq 4$ \\
& $14(\mathrm{Kruger})$ & $>7.2$ \\
pH & $>7.2$ & $<1.0$ \\
$\begin{array}{l}\text { Peroxidase positive leukocyte }\left(10^{6} / \mathrm{ml}\right)<1.0 \\
\text { MAR test (particle-bound, }\end{array}$ & $<50$ \\
motile spermatozoa, \%) & $<50$ & $<50$ \\
Immunobead test (test positive & & \\
motile spermatozoaa, \%) & $<50$ & \\
\hline
\end{tabular}

PR: Progressive, NP: Non-progressive, MAR: Mixed antiglobulin reaction

\section{TERMINOLOGY IN SPERM ANALTSIS ACCORDING TO WHO (2010) CRITERIA( ${ }^{(9)}$}

Normozoospermia: Sperm sample complying with (fertile) the WHO parameters.

Oligozoospermia: Spermatozoa concentration lower than 15 million $/ \mathrm{ml}$.

Asthenozoospermia: Proportion of progressively motile spermatozoa less than $32 \%$.

Teratozoospermia: Proportion of spermatozoa with normal morphology less than $<4 \%$.

Oligoasthenoteratozoospermia: Co-presence of above described three defects in terms of number, motility and morphology indicates severe male infertility.

Azospermia: Absence of spermatozoa in ejaculate

Criptozoospermia: Presence of spermatozoa after high speed centrifuge, which is absent in fresh sample.

Necrozoospermia: Less vital, more immotile spermatozoon in ejaculate.

Leukospermia: Presence of leukocyte in ejaculate in an amount greater than reference values.

Aspermia: Absence of ejaculate.

\section{CONCLUSION}

In approaching to an infertile couple, semen analysis appears to be the most essential first-to-be-done laboratory test for investigating the presence or absence of a male-related factor. To provide a more correct result, semen analysis should include the evaluation of at least two samples taken at four weeks interval. In terms of standardization and obtaining proper results, the importance of complying with the necessary sexual abstinence time and collection conditions should be appreciated. It should be noted that evaluation should be performed by specially trained relevant people in centers that meet certain conditions. An analysis performed in compliance with standards and concluded objectively using criteria set forth by the WHO shall play an important role in the process in which clinicians determine the route they will follow in terms of treatment. For reaching this result, this review provides 
information about semen analysis and underlines the importance of performing the analysis in the light of the criteria set forth by the WHO.

\section{REFERENCES}

1. World Health Organization. WHO Manual for the Standardised Investigation and Diagnosis of the Infertile Couple. Cambridge: Cambridge University Press, 2000

2. Dohle GR, Diemer T, Giwercman A, Jungwirth A, Kopa Z, Krausz C. Guidelines on Male Infertility, European Association of Urology, 2010.

3. Speroff L, Fritz MA. "Female infertility, Chapter 27", Clinica Gynecologic Endocrinology and Infertility, Eighth Edition, Lippincott Williams \& Wilkins, 2010, syf: 1157.

4. Speroff L, Fritz MA. "Male infertility, Chapter 30", Clinical Gynecologic Endocrinology and Infertility, Eighth Edition, Lippincott Williams \& Wilkins, 2010, syf: 1266.

5. M. Ali Kayıkçı, H. Kamil Çam, Yavuz Akman, Ali Erol. Erkek infertilitesini değerlendirmede semen analizinin özellikleri ve rolü. Düzce Tıp Fakültesi Dergisi 2002; 4: 35 -

6. Murat Örmen, Banu Önvural. Semene klinik biyokimyasal yaklaşım. Türk Klinik Biyokimya Derg 2003; 3: 155- 61.

7. Günalp S, Aktan E, Yücel A. WHO laboratuvar el kitabı: İnsan semeni ve sperm-servikal mukus etkileşimi değerlendirilmesi (Türkçeye çeviri). 4. baskı. Tıp Teknik Kitapevi, Ankara, 2002; bölüm2: 4- 32.

8. Weiske WH, Salzler N, Schroeder-Printzen I, Weidner W. Clinical findings in congenital absence of the vasa deferentia Andrologia 2000; 32: 13- 8.

9. World Health Organization. WHO Laboratory Manual for the Examination of Human Semen and Sperm-Cervical Mucus Interaction. 5th edn. Cambridge: Cambridge University Press, 2010. http://www.who.int/reproductivehealth/publications/ infertility/9789241547789/en/index.html

10. Gökçe A. Dünya Sağlık Örgütü Kriterlerine Göre Standart Semen Analizi. Turk Urol Sem 2011; 2: 1- 7
11. Jarow JP, Espeland MA, Lipshults LI. Evaluation of the azoospermic patient. J Urol 1989; 142: 62- 5.

12. World Health Organization. Laboratory Manuel for the Examination of Human Semen and Sperm-Cervical Mucus Interaction, $4^{\text {th }}$, Cambridge University Press, 1999.

13. Esat Orhon. "Erkek infertilitesi, Bölüm 12", Nedim Çiçek. Temel Üreme Endokrinolojisi ve İnfertilite. Palme Yayıncılık, 2008, syf: 109- 48.

14. Gülşen Aktan. WHO-2010 kriterlerine göre semen parametreleri neler değişti?, http://www.uroturk.org.tr/files/dogu_anadolu_ mayis_sunum/gulsen_aktan.pdf, 16.02.2011.

15. Kruger TF, Acosta AA, Simmons KF, Swanson RJ, Matta JF, Oehninger S. Predictive value of abnormal sperm morphology in in vitro fertilization. Fertil Steril 1988; 49: 112- 7 .

16. World Health Organization. Laboratory Manuel for the Examination of Human Semen and Sperm-Cervical Mucus Interaction, Cambridge University Press, 1992.

17. MacLeod J, Gold RZ. The male factor in fertility and infertility. II. Spermatozoan counts in 1000 cases of known fertility and 1000 cases of infertile marriage, J Urol 1951; 66- 436- 49.

18. MacLeod J, Gold RZ. The male factor in fertility and infertility. III. An analysis of motile activity in the spermatooa of 1000 fertile men and 1000 men in infertile marriage. Fertil Steril 1951; 2: 187- 204

19. MacLeod J, Gold RZ. The male factor in fertility and infertility. IV. Sperm morphology in fertile and infertile marriage. Fertil Steril 1951; 2: 394- 414.

20. Guzick DS, Overstreet JW, Factor-Litvak P, Brazil CK, Nakajima ST, Coutifaris C, et al. Sperm morphology, motility, and concentration in fertile and infertile men. New Engl J Med 2001; 345: 1388- 93

21. World Health Organization. Laboratory Manuel for the Examination of Human Semen and Sperm-Cervical Mucus Interaction, 2nd, Cambridge University Press, 1987.

22. McLachlan RI, Baker HW, Clarke GN, Harrison KL, Matson PL, Holden CA, et al. Semen analysis: its place in modern reproductive medical practice. Pathology 2003; 35: 2533. 